\title{
OPTIMALISASI PERANAN PEMBINAAN MANAJEMEN KOPERASI DALAM MENINGKATKAN KINERJA KOPERASI DI KABUPATEN SUMEDANG
}

\author{
Oleh : \\ Ila Karmila \\ Fakultas Ekonomi - Universitas Singaperbangsa Karawang \\ dhila112000@yahoo.co.id \\ Dede Jajang Suyaman \\ Fakultas Ekonomi - Universitas Singaperbangsa Karawang \\ jajang@fe.unsika.ac.id \\ Odang Kusmayadi \\ Fakultas Ekonomi - Universitas Singaperbangsa Karawang \\ odang.kusmayadi@fe.unsika.ac.id
}

\begin{tabular}{l}
\hline Article Info \\
\hline Article History : \\
Received 29 July - 2020 \\
Accepted 20 August - 2020 \\
Available Online \\
07 Sept - 2020
\end{tabular}

Keyword:
Coaching Cooperative
Management, Cooperative
Performance

\begin{abstract}
The essence of the problem in this research is still not optimal implementation of cooperative management by cooperatives located in Sumedang District, many cooperatives who do not report to the Department of Cooperatives, small business, medium enterprises, trade and industry Sumedang. The purpose of this research is to know the role of coaching management cooperative by the Department of Cooperatives, Small business, intermediate, trade and industry Sumedang district. The method used in this research is a qualitative method of research by examining the three cooperatives that were used as samples in this study, namely the Indonesian Employee Cooperative Cooperative Health Officer Sumedang, employee cooperative PT. PLN (Persero) Sumedang, and BMT Al Amanah Sumedang. The result of this research is that the Department of Cooperative Department of Cooperatives, small business, medium enterprises, trade, Sumedang District has a strategic role in improving the quality of cooperatives in Sumedang district through the implementation of a better cooperative management system so that cooperatives in the cooperative performance in the district can be said quality, but still there are various barriers, namely the low cooperative resource, and the unavailability of information containers to accelerate the reporting and development of cooperative material management. Recommendation of the results of this research is necessary to the role of local governments in the increase in the development budget management cooperative, provision of adequate facilities and infrastructures, improvement of the quality of human resources cooperative cooperatives through education programs and level training, and improvement of the supervision of cooperatives by the Department of Cooperatives, small business, medium enterprises, trade industry Sumedang District.
\end{abstract}

\section{PENDAHULUAN}

Koperasi sebagai sokoguru dan bagian integral dalam perekonomian nasional, maka perannya sangat penting dalam menumbuhkan dan mengembangkan perekonomian rakyat.
Namun demikian, masih dirasakan kurangnya respon dari berbagai pihak dalam memajukan dan mengembangkan koperasi walaupun payung hukum pemerintah tersedia. 
Eksistensi berkaitan erat dengan kondisi sosial masyarakat. Kondisi sosial, ekonomi, dan politik yaitu meliputi sumber daya ekonomi. Nasution dan Thamrin (2016:59) menyatakan, "Eksistensi koperasi berkaitan erat dengan kondisi sosial masyarakat. Kondisi sosial, ekonomi dan politik yaitu meliputi sumber daya ekonomi yang dimiliki oleh organisasi dan juga keadilan sosial ekonomi dari masyarakat yang bersangkutan." Pedoman Pemeringkatan Koperasi berdasarkan pada Keputusan Menteri Koperasi dan Usaha Kecil dan Menengah Nomor 06/Per/M.KUKM/III/2008 merupakan konsep pengukuran yang dapat menunjukkan kinerjakoperasi secara menyeluruh yang berlaku saat ini.

Dalam meningkatkan kinerja koperasi diperlukan Peranan Dinas Koperasi, Usaha Kecil, Menengah, Perdagangan dan Perindustrian Kabupaten Sumedang sebagai liding sektor Pemerintah Daerah Kabupaten Sumedang dalam mengatasi permasalahan tersebut, merumuskan program pembinaan manajemen koperasi dan mengimplementasikannya dalam kerangka manajemen berbasis mutu. Program pendidikan dan pelatihan sumber daya manusia koperasi menjadi salah satu prioritasnya.

Berikut ini akan dibahas pencapaian tujuan koperasi masih belum mengalami peningkatan sesuai dengan yang diharapkan oleh organisasi dalam hal ini koperasi.

Tabel 1. Data Pembinaan Koperasi Kabupaten Sumedang Tahun 2018

\begin{tabular}{|c|l|c|c|c|}
\hline No & Jenis Koperasi & $\begin{array}{c}\text { Jumlah } \\
\text { Koperasi }\end{array}$ & $\begin{array}{c}\text { Target } \\
\text { Koperasi } \\
\text { yang akan } \\
\text { dibina }\end{array}$ & $\begin{array}{c}\text { Jumlah Koperasi yang } \\
\text { telah dilakukan } \\
\text { pembinaan }\end{array}$ \\
\hline 1 & Produsen/Pertanian & 96 & 36 & 32 \\
\hline 2 & Pemasaran & 10 & 5 & 4 \\
\hline 3 & Konsumen & 410 & 136 & 24 \\
\hline 4 & Jasa & 3 & 3 & 18 \\
\hline 5 & Simpan Pinjam & 67 & 20 & $\mathbf{1 8 0}$ \\
\hline & JUMLAH & $\mathbf{5 8 6}$ & $\mathbf{2 0 0}$ & . \\
\hline
\end{tabular}

Sumber : Dinas Koperasi,UKM,Perdagangan dan Perindustrian, Tahun 2019.

Dari tabel di atas, dapat dijelaskan bahwa target pembinaan koperasi yang diharapkan oleh organisasi masih belum dapat terealisasi, hal tersebut dikarenakan adanya faktor penghambat antara lain masih terbatasnya anggaran pembinaan, terbatasnya pegawai yang mampu melaksanakan pembinaan sesuai kompetensinya, pegawai yang memiliki kompetensi terhadap pembinaan koperasi mutasi ke dinas lain dan terbatasnya sarana dan prasarana.

Rendahnya manajemen pembinaan koperasi yang dilaksanakan oleh koperasi diduga karena masih kurang diterapkannya kebijakan dalam pembinaan koperasi oleh Dinas Koperasi, Usaha Kecil, Menengah, Perdagangan dan Perindustrian, hal ini berdasarkan hasil observasi yang dapat terlihat sebagai berikut :

a. Terbatasnya pegawai pada Dinas Koperasi, Usaha Kecil, Menengah, Perdagangan dan Perindustrian yang memiliki kompetensi di bidang koperasi, karena sebagian besar mutasi ke dinas lain;

b. Terbatasnya sarana dan prasarana dalam melaksanakan program pembinaan manajemen koperasi;

c. Tidak memiiki UPTD bidang koperasi di tiap-tiap kecamatan;

d. Terbatasnya pendidikan pelatihan perkoperasian untuk Pegawai Negeri Sipil yang membidangi koperasi maupun dari Kementrian Koperasi dan Usaha Kecil dan Menengah Republik Indonesia;

e. Pelaksanaan pembinaan manajemen koperasi terbatas pada anggaran kegiatan.

Manajemen koperasi adalah proses mengoptimalkan pemanfaatan sumber daya manusia, material dan keuangan koperasi untuk mencapai tujuan koperasi yang telah ditetapkan, yaitu untuk menghasilkan manfaat yang dapat digunakan oleh anggotanya dalam upaya meningkatkan kegiatan ekonominya. Prosesmanajemen koperasi merupakan serangkaian kegiatan yang teratur,melalui tahap perencanaan,pengorganisasian,

pengarahan,pengkoordinasian dan pengendalian. Optimal mengandung maksud bahwa sumber daya koperasi dikelola secara efisien dan efektif sedangkan tujuan adalah hasil yang diharapkan biasanya diukur dengan efisiensi proses kegiatan usaha dan efektifitas dari tujuan yang dicapai.

Sumber daya koperasi sekurangkurangnya terdiri atas sumber daya manusia,sumber daya fisik (material) dan sumber daya keuangan. Sumber daya manusia koperasi terdiri atas anggota,pengurus,manajer, pegawaidan pengawasdalam mengelola sumber daya koperasi dengan sebaik-baiknya (efektif dan efisien), selanjutnya yang dilakukan pembinaan manajemen koperasi.

Permasalahan koperasi secara umum meliputi lemahnya sumber daya manusia 
(SDM) pengelola, kurangnya daya dukung permodalan, kesulitan pemasaran, praktek rentenir, gagap teknologi, kurangnya inovasi, kuantitas dan kualitas produk rendah. Adapun permasalahan yang terjadi pada operasional koperasi di Kabupaten Sumedang sebagaimana dijelaskan pada tabel berikut ini :

Tabel 2. Permasalahan Koperasi di Kabupaten Sumedang

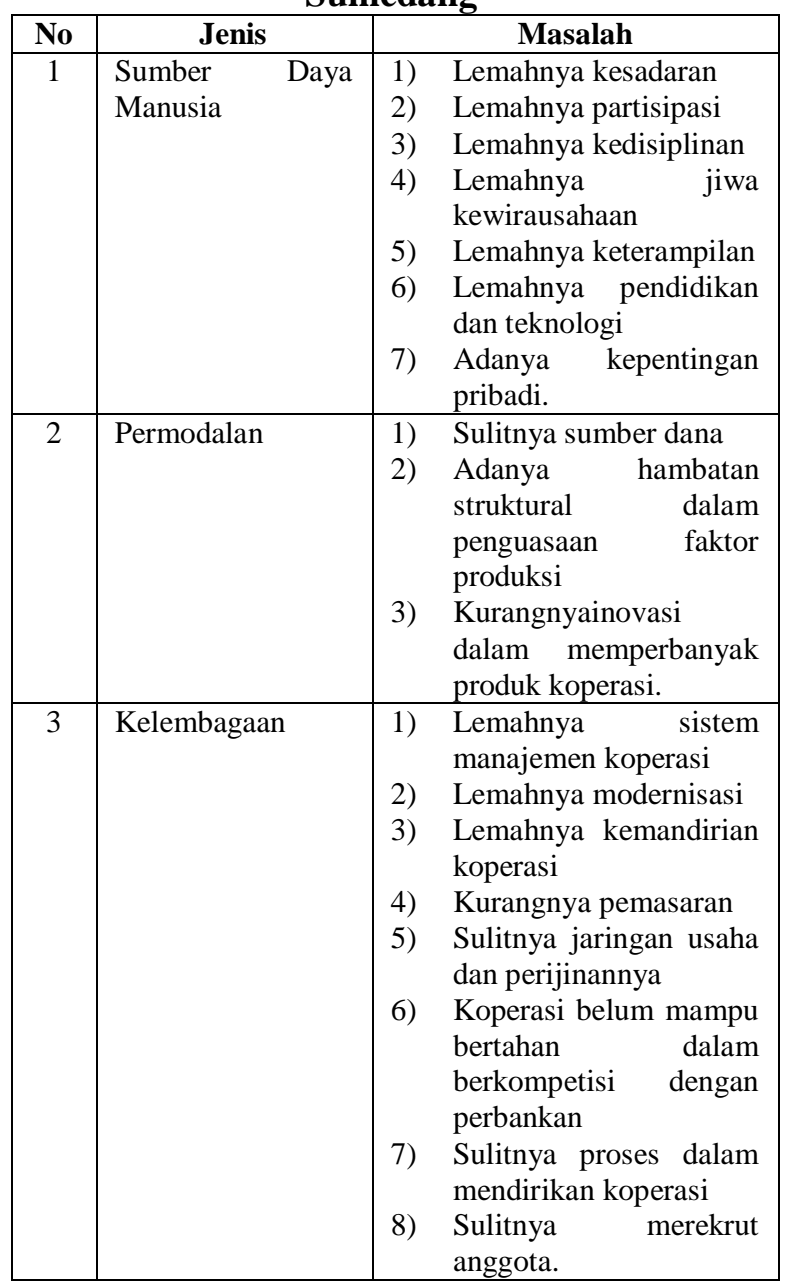

Sumber : Data hasil penelitian, diolah tahun 2019.

Dampak permasalahan koperasi yang tidak kunjung menemui jalan keluar mengakibatkan beberapa koperasi mengalami kevakuman operasional dan tidak ada rencana aksi selanjutnya dari para pengurus.

Tabel 3. Data Koperasi Aktif dan Tidak Aktif di Kabupaten Sumedang

\begin{tabular}{|c|l|c|c|c|}
\hline \multirow{2}{*}{ NO } & \multirow{2}{*}{$\begin{array}{c}\text { NAMA } \\
\text { KOPERASI }\end{array}$} & \multirow{2}{*}{ JUMLAH } & \multicolumn{2}{|c|}{ STATUS } \\
\cline { 4 - 5 } & & & & \multirow{2}{*}{ KOPERASI } \\
& & AKTIF & AKTIF \\
\hline 1 & Produsen & 96 & 65 & 31 \\
\hline 2 & Pemasaran & 10 & 9 & 1 \\
\hline 3 & Konsumen & 410 & 288 & 122 \\
\hline 4 & Jasa & 3 & 3 & 0 \\
\hline 5 & Simpan Pinjam & 67 & 58 & 9 \\
\hline & JUMLAH & $\mathbf{5 8 6}$ & $\mathbf{4 2 3}$ & $\mathbf{1 6 3}$ \\
\hline
\end{tabular}

Sumber : Dinas Koperasi, UKM, Perdagangan dan Perindustrian, Tahun 2019.

\section{KAJIAN PUSTAKA PEGEMBANGAN HIPOTESIS Koperasi}

Arifin Sition, dkk (2001:16) menjelaskan, "Kata koperasi berasal dari bahasa latin yaitu coopere, yang dalam bahasa Inggris disebut cooperation. Co artinya bersama dan operation artinya bekerja, sehingga cooperation artinya bekerja bersama-sama." Selanjutnya menurut ILO (International Labour Organization)dalam Arifin Sition (2001:16), pengertian koperasi adalah :

Cooperative defined as an asociation of persons usually of limited means, who have voluntarily joined together to achieve a common economic and thorough the formation of a deocratically contolled bussiness organization, makin euitable contribution to the capital required and accepting a fair share of the risk and benefits of undertaking.

Selanjutnya berdasarkan Undang-Undang Nomor 25 Tahun 1992 Pasal 1, "pengertian koperasi yaitu badan usaha yang beranggotakan orang-seorang atau badan hukum koperasi dengan melandaskan kegiatanya berdasarkan prinsip koperasi sekaligus sebagai gerakan ekonomi rakyat yang berdasar atas asas kekeluargaan."

Dari definisi tersebut, dapat penulis simpulkan bahwa koperasi merupakan badan usaha yang didirikan oleh sekelompok orang atau badan hukum koperasi yang dalam menjalankan usahanya dilakukan dengan adanya kerjasama para anggotanya usaha yang dijalankan harus sesuai dengan asas dan prinsip koperasi.

\section{Mananjemen Koperasi}

Sonny Sumarsono (2003:71) menyatakan, "Manajemen merupakan salah satu bagian penting dari organisasi koperasi. Berhasil tidaknya suatu koperasi sangat tergantung pada mutu dan kerja dalam bidang manajemennya". Apabila orang-orang alam manajemen ini memiliki kejujuran, kecakapan dan giat dalam bekerja maka besarlah kemungkinannya koperasi akan maju pesat atau atau setidak tidaknya tendensi untuk terjadinya kebangkrutan dapat ditanggulangi. Tetapi sebaliknya, apabila orang-orang ini tidak cakap, curang atau tidak berwibawa tentulah koperasi pun akan mundur atau tidak semaju seperti yang diharapkan. Kita sering melihat, terjadinya kesulitan-kesulian dalam soal keuangan, soal yang menarik perhatian anggota pada koperasi, pemasaran barang-barang, organisasi yang kacau dan sebagainya. Kesulitan-kesulitan 
semacam itu pangkal persoalannya karena ketidakberesan pada manajemen.

Sonny Sumarsono (2003:75) menyatakan, "peranan manajemen adalah membuat koperasi berhasil dalam mencapai tujuannya, baik tujuan para anggotanya, misalnya untuk mencapai perbaikan tingkat hidup atau sedikitnya meringankan biaya hidup sehari-hari, maupun tujuan yang telah ditetapkan oleh pemerintah. Dalam hal yang pertama, manajemen merupakan unsur pembuat keputusan yang telah digariskan oleh rapat anggota. Dalam hal yang kedua, pemerintah menentapkan bahwa koperasi bertujuan untuk menambah kesejahteraan anggota dan masyarakat dalam rangka mencapai masyarakat adil dan makmur berdasarkan pancasila.

Seperti badan usaha yang lain, koperasi juga akan menghadapi berbagai persoalan dalam mencapai tujuan. Sebagian besar tugas manajemen adalah memecahkan persoalanpersoalan itu dan membuat putusan-putusan yang akan menuju sasaran yang dikehendaki.

Sonny Sumarsono (2003:75) menjelaskan, langkah-langkah yang diambil dalam memecahkan sesuatu persoalan adalah :

a. Membuat persoalan yang dihadapi menjadi jelas;

b. Mencari alternatif-alternatif untuk memecahkannya;

c. Memilih salah satu cara atau alternatif yang paling sesuai dengan tujuan koperasi;

d. Menilai hasil cara tersebut.

\section{Kinerja Koperasi}

Menurut Kamus Besar Bahasa Indonesia "Kinerja adalah sesuatu yang dicapai, prestasi yang diperlihatkan, atau kinerja merupakan kemampuan kerja. Priansa dan Suwatno (2013:196) mendefinisikan, "kinerja sebagai hasil yang dicapai seseorang menurut ukuran yang berlaku, dalam kurun waktu tertentu, berkenaan dengan pekerjaan serta perilaku dan tindakannya." Sementara itu, Wilson Bangun (2012:231) mendefinisikan kinerja atau performance sebagai hasil pekerjaan yang dicapai seseorang berdasarkan persyaratanpersyaratan pekerjaan.

Suryadi Prawirosentono menyatakan,"kinerja sebagai hasil kerja yang dicapai oleh seseorang atau sekelompok orang dalam suatu organisasi, sesuai dengan wewenang dan tanggungjawab masing-masing dalam rangka upaya mencapai tujuan organisasi bersangkutan secara legal, tidak melanggar hukum dan sesuai dengan moral maupun etika." Pemeringkatan Koperasi $\begin{array}{ccc}\begin{array}{c}\text { Menurut } \\ \text { Koperasi Peraturan Menteri }\end{array} & \text { Negara } \\ \text { dan } & \text { UMKM } & \text { Nomor }\end{array}$ 06/Per/M.KUKM/III/2008 tentang Pedoman Pemeringkatan Koperasi Pasal 1 Ayat 5, pemeringkatan koperasi adalah suatu kegiatan penilaian terhadap kondisi dan atau kinerja koperasi melalui sistem pengukuran yang obyektif dan transparan dengan kriteria dan persyaratan tertentu yang dapat menggambarkan tingkat kualitas dari suatu koperasi.

\section{Tujuan Pemeringkatan Koperasi}

Berdasarkan Peraturan Menteri Negara Koperasi dan UMKM No. 06/Per/M.KUKM/III/2008 tentang Pedoman Pemeringkatan Koperasi Pasal 2, tujuan pemeringkatan koperasi adalah :

a. Mengetahui kinerja koperasi dalam suatu periode tertentu;

b. Menetapkan peringkat kualifikasi koperasi;

c. Mendorong koperasi agar menerapkan prinsip-prinsip koperasi dan kaidah bisnis yang sehat.

\section{Aspek-Aspek Penilaian}

Menurut Peraturan Menteri Negara Koperasi dan UMKM Nomor 06/Per/M.KUKM/III/2008 tentang Pedoman Pemeringkatan Koperasi Pasal 4 Ayat (1), agar dapat menggambarkan secara utuh mengenai badan usaha koperasi, maka landasan berfikir Pengembangan Sistem Pemeringkatan Koperasi didasarkan pada tiga sifat koperasi yaitu Koperasi Sebagai Badan Usaha, Koperasi sebagai kumpulan orang dan koperasi sebagai Akselerasi Pembangunan. Agar sistem pemeringkatan koperasi dapat memberikan hasil yang menggambarkan secara utuh koperasi sebagai badan usaha, maka indikator penilaian dalam sistem pemeringkatan koperasi mencakup aspek-aspek yang mewakili kecirian sebagai badan usaha dan kecirian sebagai koperasi berkualitas yaitu :

a. Aspek Badan Usaha Aktif

b. Aspek Kinerja Usaha yang semakin kuat

c. Aspek Kohesivitas dan Partisipasi Anggota

d. Aspek Orientasi Kepala Pelayanan Anggota

e. Aspek pelayanan kepada masyarakat

f. Aspek kontribusi terhadap pembangunan daerah

\section{Pengembangan Hiptosesis}

Berdasarkan Surat Edaran Deputi Bidang Kelembagaan Nomor 9 Tahun 2018 tentang Pelaksanaan Pemeringkatan Koperasi dan Lembaga Independen Pemeringkatan Koperasi, Koperasi sebagai badan usaha yang didirikan oleh dan berbasiskan angotanya perlu membangun dirinya agar menjadi sehat, tangguh dan mandiri berdasarkan prinsip 
koperasi, sehingga mampu meningkatkan kesejahteraan anggota dan masyarakat. Oleh karena itu, diperlukan upaya untuk meningkatkan mutu dan kinerja koperasi melalui program pemerintakatan koperasi. Tujuan pemeringkatan koperasi adalah :

a. Mengetahui tingkat kinerja koperasi dalam suatu periode tertentu;

b. Menunjukkan keberhasilan dan eksistensi koperasi kepada pihak-pihak yang berkepentingan;

c. Tumbuhnya kesadaran koperasi akan pentingnya hasil pemeringkatan koperasi;

d. Meningkatnya kepercayaan anggota koperasi, masyarakat, mitra kerja dan pemangku kepentingan koperasi;

e. Meningkatnya lembaga pemeringkat yang independen dan kredibel serta memiliki kompetensi dan profesionalisme di bidang perkoperasian.

Pedoman pemeringkatan koperasi seyogyanya selalu mengalami pembaharuan mengikuti perkembangan zaman. Sebelum sampai ke tahap yang terbaru hingga saat ini, Kementerian Koperasi dan UKM RI telah menerbitkan pedoman pemeringaktan koperasi melalui Peraturan Menteri Koperasi dan UKM RI Nomor 22/Per.M.KUKM/IV/2007, selanjutnya melalui Peraturan menteri Koperasi dan UKM RI Nomor 21/er/M.KUKM/IX/2015 hingga saat ini terbit Surat Edaran Deputi Bidang Kelembagaan Nomor 9/2018 tentang Pelaksanaan Pemeringkatan Koperasi dan Lembaga Independen Pemeringkat Koperasi yang menindaklanjuti Pasal 151 hurup (P) Peraturan Menteri Koperasi dan UKM RI Nomor 9 Tahun 2018 tentang Penyelenggaraan dan Pembinaan Perkoperasian.
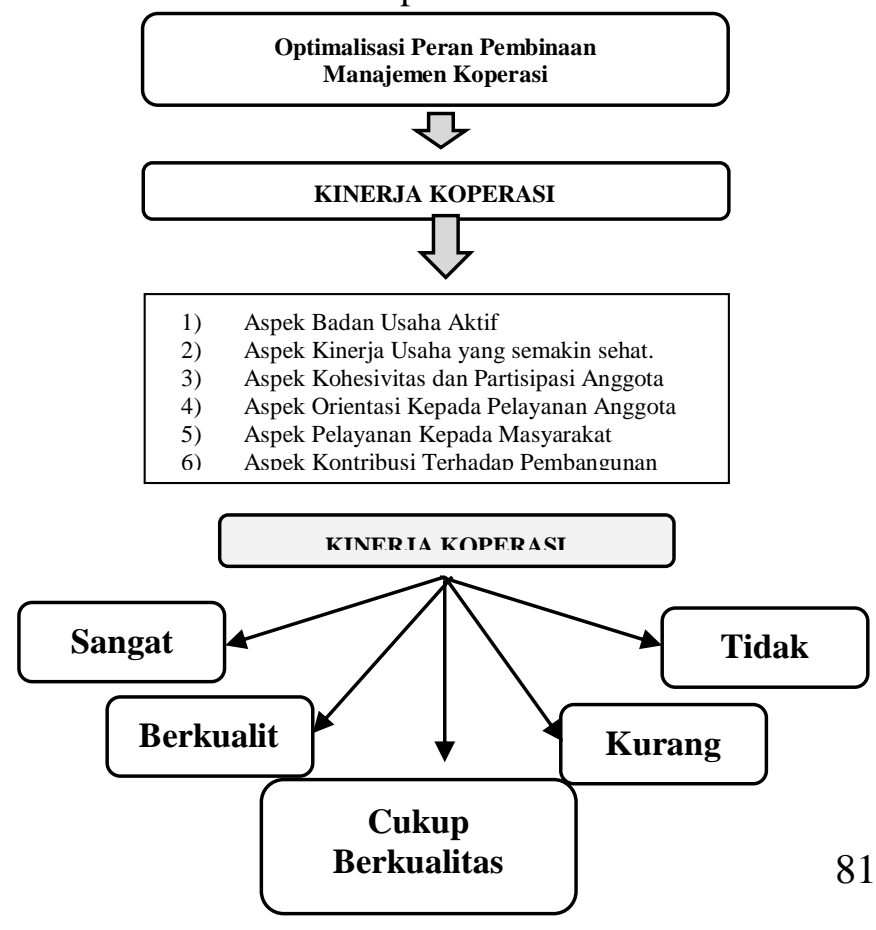

\section{METODE PENELITIAN}

Sugiyono (2016:227) menjelaskan, Metode kuantitatif dan kualitatif sering dipasangkan dengan nama metode yang tradisional, dan metode baru, metode positivistik dan metode pospositivistik, metode scientific dan metode artistik, metode konfirmasi dan discovery/temuan, serta kuantitatif dan interpretif. Jadi metode kuantitatif sering dinamakan metode tradisional, positivistik, scientific dan metode konfirmatif. Selanjutnya metode kualitatif sering dinamakan sebagai metode baru, postpositivistik, scientific dan metode konfirmatif. Selanjutnya metode kualitatif sering dinamakan sebagai metode baru, postpositivistik, artistik dan interpretive research. Kedua peneliti kuantitatif dan kualitatif, sama-sama akan mencari temuan dengan cara yang berbeda. Penelitian kualitatif berarti proses eksplorasi dan memahami makna perilaku individu individu dan kelompok, menggambarkan masalah sosial atau masalah kemanusiaan. Proses penelitian mencakup membuat pertanyaan penelitian dan prosedur yang masih bersifat sementara, mengumpulkan data yang parsial ke dalam tema, dan selanjutnya memberikan interpretasi terhadap makna suatu data. Kegiatan akhir adalah membuat laporan ke dalam struktur yang fleksibel.

Dalam penelitian kualitatif instrumennya adalah orang atau human instrument yaitu peneliti itu sendiri. Untuk dapat menjadi instrumen maka peneliti harus memiliki bekal teori yang luas sehingga mampu bertanya, menganalisis, memotret, dan mengkonstruksi situasi sosial yang diteliti menjadi lebih jelas dan bermakna. Untuk mendapatkan pemahaman yang lebih luas dan mendalam terhadap situasi sosial yang diteliti, maka tekhnik pengumpulan data bersifat triangulasi, yaitu menggunakan berbagai pengumpulan data secara gabungan / simultan. Metode kualitatif digunakan untuk mendapatkan data yang mendalam suatu data yang mengandung makna. Makna adalah data yang sebenarnya, data yang pasti yang merupakan suatu nilai di balik data yang tampak. Oleh karena itu, dalam penelitian kualitatif tidak menekankan pada generalisasi tetapi lebih menekankan pada makna. Generalisasi dalam penelitian kualitatif dinamakan transferability.

Di dalam penelitian ini, peneliti menggunakan teknik penelitian studi kasus. Studi kasus merupakan strategi yang cocok bila pokok 
pertanyaan suatu penelitian berkenaan dengan how and why.

Peneliti menggunakan studi kasus karena penulis beranjak dari sebuah permasalahan yang berada di Kabupaten Sumedang yang berhubungan dengan optimalisasi peran pembinaan manajemen koperasi dalam meningkatkan kinerja koperasi di Kabupaten Sumedang (Koperasi Pegawai Republik Indonesia KORPS Pegawai Kesehatan Sumedang, Koperasi Karyawan (KOKAR) PT. PLN (Persero) UID Jawa Barat UP3 Sumedang, Koperasi Simpan Pinjam dan Pembiayaan Syari'ah BMT Al-Amanah Sumedang). Studi kasus adalah metode riset yang menggunakan berbagai sumber data yang bisa digunakan untuk peneliti menguasai dan menjelaskan secara komprehensif berbagai aspek individu, kelompok, suatu program, organisasi atau peristiwa secara sistematis. Karena itu, peneliti dapat menggunakan wawancara mendalam kuisioner hasil survei rekaman dan bukti-bukti fisik lainnya. Penelitian ini akan menggunakan metode penelitian kualitatif, tentunya peneliti akan menggunakan informan dalam pemenuhan aspek tujuan penelitian. Informan diperlukan untuk memperoleh informasi secara akurat dan tepat.

\section{Tabel 2. Informan Penelitian}

\begin{tabular}{|c|l|c|}
\hline No & \multicolumn{1}{|c|}{ Jabatan } & Jumlah \\
1 & $\begin{array}{l}\text { Ketua Koperasi Pegawai Republik } \\
\text { Indonesia KORPS Pegawai Kesehatan } \\
\text { Sumedang }\end{array}$ & 1 orang \\
\hline 2 & $\begin{array}{l}\text { Badan Pengawas Koperasi Pegawai } \\
\text { Republik Indonesia KORPS Pegawai } \\
\text { Kesehatan Sumedang }\end{array}$ & 1 orang \\
\hline 3 & $\begin{array}{l}\text { Ketua Koperasi Koperasi Karyawan } \\
\text { PLN Sumedang }\end{array}$ & 1 orang \\
\hline 4 & $\begin{array}{l}\text { Badan Pengawas Koperasi Karyawan } \\
\text { PLN Sumedang }\end{array}$ & 1 orang \\
\hline 5 & $\begin{array}{l}\text { Ketua Koperasi Simpan Pinjam dan } \\
\text { Pembiayaan Syari'ah BMT Al-Amanah } \\
\text { Sumedang }\end{array}$ & 1 orang \\
\hline 6 & $\begin{array}{l}\text { Badan Pengawas Koperasi Simpan } \\
\text { Pinjam dan Pembiayaan Syari'ah BMT } \\
\text { Al-Amanah Sumedang }\end{array}$ & 1 orang \\
\hline & Jumlah & 6 Orang \\
\hline
\end{tabular}

Sumber : Data hasil penelitian, diolah tahun 2019.

\section{HASIL PENELITIAN DAN} PEMBAHASAN

Display Data Pembinaan manajemen koperasi oleh Dinas Koperasi, Usaha Kecil, Menengah, Perdagangan dan Perindustrian Kabupaten Sumedang

Display data dalam penelitian ini peneliti mengembangkan sebuah deskripsi inforasi yang tersusun untuk menarik kesimpulan dan pengambilan tindakan. Display data atau penyajian data yang lazim digunakan lada langkah ini adalah dala bentuk teks naratif. Untuk menganalisis data dengan penyajian data (data display) dalam penelitian ini peneliti menggunakan tiga cara yaitu wawancara mendalam, observasi lapangan, dan studi dokumentasi untuk mendapatkan data. Dalam wawancara mendalam ini dijelaskan sebelumnya mekanisme yang akan dilakukan oleh peneliti.

Hambatan Dalam Rangka pembinaan manajemen koperasi oleh Dinas Koperasi, Usaha Kecil, Menengah, Perdagangan dan Perindustrian Kabupaten Sumedang

Pembinaan koperasi adalah suatu arahan, atau tindakan yangdiberikan Kementerian Koperasi dan Usaha Kecil dan Menengahterhadap lembaga pendidikan dan pelatihan bagi sumberdaya manusiakoperasi dan pengusaha mikro, kecil dan menengah. Pembinaan koperasidilakukan melalui seleksi, koordinasi, fasilitasi, bimbingan, arahan,supervisi, monitoring dan evaluasi (Peraturan Menteri Koperasi danUsaha Kecil dan Menengah Republik Indonesia Nomor10/Per/M.Kukm/Ix/2015 Tentang Kelembagaan Koperasi).

Dinas Koperasi, Usaha Kecil, Menengah, Perdagangan dan Perindustrian dalam melaksanakan pembinaan tekhnis terhadap koperasi dilakukan dengantata cara sebagai berikut:

a. Memantau perkembangan kegiatan koperasi secara berkalamelalui laopran kinerja koperasi yang bersangkutan;

b. Melakukan pembinaan secara menyeluruh yang menyangkutorganisasi, usaha, administrasi keuangan serta pelaksanaanprogram pembinaan kepada anggota.

Dinas Koperasi, Usaha Kecil, Menengah, Perdagangan dan Perindustrian dalam memberikan pembinaan terhadap koperasi dapat berbentuk sebagaiberikut:

a. Perbaikan manajemen koperasi yang meliputi aspek kelembagaan,usaha dan keuangan;

b. Perkuatan modal;

c. Penilaian kesehatan koperasi;

d. Pendidikan dan pembinaan usaha anggota;

e. Pemberian tindakan administratif.

Dinas Koperasi, Usaha Kecil, Menengah, Perdagangan dan Perindustrian dalammelaksanakan pengawasan terhadap 
koperasi dengan menggunakanunsur-unsur yang harus dipantau yaitu meliputi:

a. Jenis kelengkapan laporan setiap stahun sekali

b. Ketepatan dan kesesuaian waktu pelaporan yaitu 30 (tia puluh) harisetelah RAT dilaksanakan dan RAT selama 3 (tiga) tahun berturutturutharus dlaporkan pelaknsanaannya;

c. Kelengkapan informasi laporan sesuai dengan Standart OperasionalManajemen (SOM) yang diatur oleh Peraturan Menteri;

d. Kesesuaian pelakuan akuntasi yang menyangkut pengakuan,pengukuran, penyajian dan pengungkapan seluruh pemikirandilakukan berdasarkan prinsip akuntansipedoman umum koperasiyang berlaku secara umum;

e. Kesesuaian penyajian laporan keuangan yang memenuhi syaratkarakteristik kualitatif laporan keuangan yang dapat dipahami,relevan, handal dan dapat diperbandingkan.

Dalam melaksanakan pembinaan dan pengawasan terhadapkoperasi, Dinas Koperasi, Usaha Kecil, Menengah, Perdagangan dan Perindustrian terdapathambatan-hambatan meliputi:

a. Tidak disiplinnya pengurus koperasi dalam menyampaikan laporanRAT koperasi setiap tahun kepada Dinas Koperasi, Usaha Kecil, Menengah, Perdagangan dan Perindustrian

b. Beberapa oknum pengurus koperasi yang memanfaatkan koperasidemi kepentingan pribadi atau kelompok;

c. Kurangnya intensitas pembinaan oleh Dinas Koperasi, Usaha Kecil, Menengah, Perdagangan dan Perindustrian kepada koperasi-koperasi.

d. Pengurus koperasi dan masyarakat perlu disadarkan akan hukumperkoperasian dengan dilakukan penyuluhan pendidikan dan pelatihanbagi masyarakat secara terusmenerus agar tercipta budaya hukumkoperasi yang sesuai dengan konsep hukum perkoperasian.

e. Perlu meningkatkan kapabilitas pegawai dalampembinaan dan pengawasan koperasi, disamping itu penambahan pegawaidalam melaksanakan tugas pembinaan dan pengawasan yang efektifmerupakan suatu keniscayaan.

Upaya Yang dilakukan untuk mengatasi Hambatan Dalam Rangka pembinaan manajemen koperasi oleh Dinas Koperasi UMKM Perdagangan dan Perindustrian Kabupaten Sumedang
Untuk mengatasi tidak disiplinnya pengurus koperasi dalammenyampaikan laporan RAT setiap tahun, maka pihak Dinas Koperasi, Usaha Kecil, Menengah, Perdagangan dan Perindustrian Kabupaten Sumedang dapat menghubungi koperasi yang bersangkutan untuk secepatnya menyampaikan laporan RAT tahunan yang dikelola oleh pengurus koperasi tersebut. Apabila dalam menghubungi koperasi yang bersangkutan dirasa belum cukup maka dimungkinkan Dinas Koperasi, Usaha Kecil, Menengah, Perdagangan dan Perindustrian Kabupaten Sumedang akan mendatangi koperasi tersebut guna memperoleh informasi mengenai laporan RAT koperasi. Kemudian apabila koperasi yang bersangkutan tidak dapat memberikan keterangan laporan RAT selama tiga tahun berturut-turut atau pasif tidak menjalankan aktivitas perkoperasian yaitu menghimpun dan menyalurkan dana kepada msyarakat, maka Dinas Koperasi, Usaha Kecil, Menengah, Perdagangan dan Perindustrian Kabupaten Sumedang dapat menggabungkan dengan koperasi lain atau membubarkannya dengan mencabut akta pendirian koperasi tersebut. Pembubaran koperasi yang tidak aktif selama tiga tahun berturtu-turut sesuai dengan Peraturan Mentri Koperasi dan Usaha Kecil dan Menengah Nomor 10 Tahun 2015 tentang Kelembagaan Koperasi. Pelaksanaan pembubaran koperasi dilakukan dibawah pengawasan Menteri.

Mengenai oknum pengurus koperasi yang memanfaatkan koperasidemi kepentingan pribadi atau kelompok, hal ini sering terjadi didaerah pasar-pasar tradisional. Dimana biasanya pengurus koperasimemanfaatkan KTP palsu atau ikut menggunakan uang pinjaman darimasyarakat untuk kepentingan pribadi. Munculnya pihakpihak yangmenjadi makelar kredit bagi pedagang pasar dan sekitarnya ini sangatmencoreng nama baik koperasi. Peristiwa ini bertentangan denganUndang-Undang Nomor 25 Tahun 1992 tentang fungsi dan peranKoperasi yang berusaha untuk mewujudkan dan mengembangkanperekonomian nasional yang merupakan usaha bersama berdasarkanatas asas kekeluargaan dan demokrasi ekonomi. Dengan memberantaskoperasi kredit, diharapkan sikap perilaku masyarakat sekitar dapatberubah dan meningkatkan pendapatan perekonomian mereka denganbekerja tekun dan rajin. Tumbuhnya makelar kredit dalam dirikoperasi sebenarnya hanya untuk kepentingan beberapa pihak saja. Kurangnya keaktifan anggota dalam ikut mengawasi dankurangnya kesadaran anggota dalam memiliki dan mempertahankankoperasi dapat dinilai dari sedikitnya anggota yang hadir pada saatRAT. Rapat yang seharusnya menjadi 
tempat berkeluh kesah inisering anggota lalaikan. Seharusnya pengurus mewajibkan anggotaaktif dan pasif dalam mengikuti RAT, sehingga dapat bersama-samamengawasi koperasi dan tentunya koperasi akan berjalan sehat sesuaidengan aturan yang ada. Dinas Koperasi, Usaha Kecil, Menengah, Perdagangan dan Perindustrian Kabupaten Sumedang dalam mengatasi masalah yang berkaitan dengan oknumoknumyang tidak menjalankan kegiatan perkoperasian sesuaiUndang-Undang akan diberikan sanksi tegas. Jika dirasa koperasisudah tidak dapat dipertahankan karena sikap perilaku pihakpihakyang tidak bertanggungjawab tersebut Dinas Koperasi, Usaha Kecil, Menengah, Perdagangan dan Perindustrian Kabupaten Sumedang dapat melakukan pembubaran koperasikarena kegiatan koperasi bertentangan dengan ketertiban umumdan/atau kesusilaan yang dinyatakan berdasarkan keputusanpengadilan yang berkekuatan hukum tetap, hal ini sesuai denganPeraturan Menteri Koperasi dan Usaha Kecil dan Menengah Nomor 10Tahun 2015 tentang Kelembagaan Koperasi. Kemudian apabila paraanggota koperasi bersangkutan merasa dirugikan oleh pihak-pihakyang tidak bertanggungjawab, maka anggota koperasi dapatmengusulkan mengenai pembubaran koperasi melalui rapat anggota.Pembubaran koperasi oleh rapat anggota dilaporkan kepada Menteri.

Kurangnya intensitas pembinaan oleh Dinas Koperasi UMKM Perdagangan dan Perindustrian Kabupaten Sumedang kepada koperasi-koperasi juga menjadihambatan. Kurangnya pegawai menjadi faktor yang menghambatkeaktifan Dinas Koperasi, Usaha Kecil, Menengah, Perdagangan dan Perindustrian Kabupaten Sumedang hal ini yang menjadi alasanintensitas pertemuan antara Dinas Koperasi, Usaha Kecil, Menengah, Perdagangan dan Perindustrian Kabupaten Sumedang denganpengurus koperasi hanya terjadi ketika suatu koperasi akanmengadakan RAT. Intensitas pertemuan/kunjungan dariDinas Koperasi, Usaha Kecil, Menengah, Perdagangan dan Perindustrian Kabupaten Sumedang Kabupaten Karanganyar ke koperasikoperasidi daerahnya harus ditambah. Selain itu pelatihanpelatihanbagi koperasi juga harus diagendakan secara rutin. Bila koperasisendiri tidak aktif dalam mengikuti, maka Dinas Koperasi, Usaha Kecil, Menengah, Perdagangan dan Perindustrian Kabupaten Sumedang harus berani mengambil tindakan berupa pemberian sanksi agarkoperasi yang tidak aktif jera. Keaktifan tidak hanya dari penguruskoperasi-koperasi daerah, namum pegawai sebagai struktur yang adadalam Dinas Koperasi, Usaha Kecil, Menengah, Perdagangan dan Perindustrian Kabupaten Sumedang juga harus menyadari kurangnyakeaktifan mereka dalam berkunjung. Apabila selama iniDinas Koperasi, Usaha Kecil, Menengah, Perdagangan dan Perindustrian Kabupaten Sumedang berkunjung apabila mendapatkan undanganRAT dari koperasi, maka kebiasaan itu harus diubah. Sebagai dinasyang dipercaya membina dan mengawasi Dinas Koperasi, Usaha Kecil, Menengah, Perdagangan dan Perindustrian Kabupaten Sumedangjuga harus memberikan kunjungan rutin terhadap koperasi-koperasidaerah terutama koperasi di Kabupaten Karanganyar yang kurangaktif. Kurangnya pegawai menjadi kendala mereka dalam pembinaandan pengawasan. Dinas Koperasi, Usaha Kecil, Menengah, Perdagangan dan Perindustrian Kabupaten Sumedang beranggapan bahwa 15orang pegawai tidak mumpuni dalam menangai 1146 koperasi yangada di Kabupaten Karanganyar. Selain itu faktor anggaran yangterbatas juga menjadi kendala bagi Dinas Koperasi, Usaha Kecil, Menengah, Perdagangan dan Perindustrian Kabupaten Sumedang dalammenjalankan aktifitas yang berhubungan dengan pembinaan danpengawasan koperasi-koperasi. (Hasil wawancara dengan BapakAldolfus Joce, Kepala Dinas Koperasi, Usaha Kecil, Menengah, Perdagangan dan Perindustrian Kabupaten Sumedang.

Berdasarkan hasil wawancara dan temuan penelitian di lapangan maka dapat penulis simpulkan bahwa Dinas Koperasi, Usaha Kecil, Menengah, Perdagangan dan Perindustrian Kabupaten Sumedang dalam melakukanpembinaan koperasi dilaksanakan dengan cara memantau perkembangankegiatan koperasi secara berkala melalui perbaikan manajemen koperasiyang meliputi aspek kelembagaan, usaha dan keuangan, perkuatan modal,penilaian kesehatan koperasi, pendidikan dan pembinaan usaha anggota,pemberian tindakan administratif. Sedangkan Dinas Koperasi, Usaha Kecil, Menengah, Perdagangan dan Perindustrian Kabupaten Sumedang dalam melaksanakan pengawasan terhadapkoperasi dilaksanakan dengan cara pembinaan, pemantauan danpemeriksaan koperasi.

Dinas Koperasi, Usaha Kecil, Menengah, Perdagangan dan Perindustrian Kabupaten Sumedangdalam melaksanakanpembinaan dan pengawasan terhadap koperasi-koperasi di daerahKabupaten Karanganyar terdapat hambatanhambatan yaitu tidakdisiplinnya pengurus koperasi dalam menyampaikan laporan RATkoperasi setiap tahun kepada Dinas Koperasi, Usaha Kecil, Menengah, Perdagangan dan Perindustrian Kabupaten Sumedang, beberapa oknum pengurus 
koperasi yang memanfaatkankoperasi demi kepentingan pribadi atau kelompok, kurangnya intensitas pembinaan oleh Dinas Koperasi, Usaha Kecil, Menengah, Perdagangan dan Perindustrian Kabupaten Sumedang kepadakoperasi-koperasi. Solusi untuk mengatasi tidak disiplinnya penguruskoperasi dalam menyampaikan laporan RAT tahunan, Dinas Koperasi, Usaha Kecil, Menengah, Perdagangan dan Perindustrian Kabupaten Sumedangmenghubungi pengurus koperasi yangbersangkutan untuk secepatnya mnyampaikan laporan RAT tahunan.Kemudian solusi untuk mengatasi oknum pengurus koperasi yangmemanfaatkan koperasi demi kepentingan pribadi atau kelompok, makaDinas Koperasi, Usaha Kecil, Menengah, Perdagangan dan Perindustrian Kabupaten Sumedang melakukan investigasisecara mendalam yang kemudian akan ditindak lanjuti sesuai denganperaturan yang berlaku.

Solusi mengenai kurangnya intensitas pembinaandan pengawasan oleh Dinas Koperasi, Usaha Kecil, Menengah, Perdagangan dan Perindustrian Kabupaten Sumedangkepada koperasi-koperasi daerah yang disebabkan kurangnya pegawai dananggaran, maka Dinas Koperasi, Usaha Kecil, Menengah,Perdagangan dan Perindustrian Kabupaten Sumedangmengajukan penambahan pegawai dan anggaran.

\section{Temuan Hasil Penelitian dan Penafsiran}

Berdasarkan hasil penjelasan hasil penelitian, uji kredibeilitas melalui proses wawancara dimana dari ke lima informan yang diwawancarai memberikan inplementasi yang sama terkait dengan peran pemerintah dalam pembinaan manajemen koperasi di Kabupaten Sumedang.

Hasil penelitian mengungkapkan bahwa dari penilaian kinerja koperasi yang dilihat dari dokumen Laporan Tahunan Koperasi yang disampaikan melalui Rapat Anggota Tahunan dari tiga koperasi yaitu KPRI KPKS Sumedang, Koperasi Karyawan PT PLN (Persero Cabang Sumedang) dan BMT Al Amanah Sumedang dilihat dari Aspek Badan Usaha Aktif, Aspek Kinerj usaha yang semakin Baik, Aspek Kohesivitas dan Partisipasi Anggota, Aspek Orientasi Kepada Pelayanan Anggota , Aspel Pelayanan Kepada Masyarakat, dan Aspek Kotribusi Terhadap Pembangunan dapat dikategorikan berkualitas.

Dari hasil penelitian tesebut, bahwa dapat dikategorikan berkualitas hal ini dibuktikan masih banyaknya komponen komponen permodalan koperasi yang masih harus ditunjang dengan peran serta pemerintah maupun badan usaha milik pemerintah untuk membantu koperasi dari unsur permodalan dan pengembangan sumber daya manusia pengelola koperasi.

Kondisi koperasi setelah dilakukan pembinaan manajemen koperasi oleh Pemerintah Daerah Kabupaten Sumedang dalam hal ini sudah mengalami ke arah kemajuan atau ada peningkatan walaupun berbeda jauh dari tahun tahun sebelumnya karena banyaknya faktor persaingan bisnis dengan lembaga keuangan perbankan yang memberikan kemudahan kemudahan sehingga menarik para nasabah untuk lebih menitipkan uangnya di Bank ketimbang ikut menjadi anggota koperasi dan menitipkan uangnya di koperasi.

\section{KESIMPULAN}

Berdasarkan hasi lpenelitian dan pembahasan maka dapat diambil kesimpulan sebagai berikut :

a. Pembinaan manajemen koperasi yang dilaksanakan secara rutin oleh Dinas Koperasi Dinas Koperasi, Usaha Kecil, Menengah, Perdagangan dan Peindustrian Kabupaten Sumedang dalam melakukan pembinaan koperasi dilaksanakan dengan memantau perkembangan kegiatan koperasi secara berkala melalui perbaikan manajemen koperasi yang meliputi aspek kelembagaan, usaha dan keuangan, penguatan modal, penilaian kesehatan koperasi, pendidikan dan pembinaan usaha anggota, pemberian tindakan administrative telah memberikan dampak positif dalam peningkatan peran koperasi di Kabupaten Sumedang.

b. Dalam melaksanakan pengawasan terhadap koperasi dilaksanakan terdapat berbagai hambatan hambatan yaitu tidak disiplinnya pengurus koperasi dalam menyampaikan laporan RAT koperasi setiap tahun kepada Dinas Koperasi, Usaha Kecil, Menengah, Perdagangan dan Perindustrian Kabupaten Sumedang, beberapa oknum pengurus koperasi yang memanfaatkan koperasi demi kepentingan pribadi atau kelompok, kurangnya intensitas pembinaan oleh Dinas Koperasi, Usaha Kecil, Menengah, Perdagangan dan Perindustrian Kabupaten Sumedang kepada koperasi koperasi di Kabupaten Sumedang. Hal ini membuktikan walaupun sudah dilakukan pembinaan terhadap koperasi koperasi di Kabupaten Sumedang masih ada yang koperasi yang tidak disiplin terhadap kewajiban pelaporan kegiatan koperasi kepada Dinas Koperasi, Usaha Kecil, Menengah, Perdagangan dan Perindustrian Kabupaten Sumedang selaku instansi yang berwenang untuk memberikan ijin operasional pelaksanaan usaha - usaha koperasi. 


\section{REFERENSI}

Ahmad.(2012). Akuntansi Biaya. Edisi 3. Bandung : Salemba Empat.

Baswir Revsond (2010). Koperasi Indoneaia. Edisi Pertama. Yogyakarta : BPFE

Bangun, Wilson.(2013).Manajemen Sumber Daya Manusia. Jakarta : Erlangga.

Djam'an Satori dan Aan Komariah (2017). Metodologi Penelitian Kualitatif. Bandung : Alfabeta.

Gaspersz Vincent.(2012). All In One Production and Inventori Management, Edisi 8. Bogor.

Gunawan Imam.(2016). Metode Penelitian Kualitatif. Jakarta : Bumi Aksara.

Hardiansyah (2010). Kualitas Pelayanan Publik. Yogyakarta : Gava Media.

Kuncoro Mudrajad.(2013). Metode Riset Untuk Bisnis dan Ekonomi. Edisi 4, Jakarta Erlangga.

Kenneth D. Bailey (2014). Methods of Social Research. Jakarta : Rajawali Grafindo Persada.

Keputusan Menteri UKM No. 06/Per/M.KUKM/III/2008 Tentang Pedoman Pemeringkatan Koperasi. https://www.jdih.setneg.go.id diakses pada tanggal 1 November 2019.

Lexy J. Moleong (2016). Metodologi Penelitian Kualitatif Edisi Revisi. Bandung PT. Remaja Rosdakarya.

Laporan Tahunan Tahun Buku 2018 BMT AlAmanah Sumedang.

Laporan Tahunan Tahun Buku 2018 Koperasi Pegawai Republik Indonesia (KPRI) Pegawai Kesehatan Kabupaten Sumedang.

Laporan Tahunan Tahun Buku 2018 Koperasi Karyawan Industri (KOPKARIN) PT. Kahatex Kabupaten Sumedang

Muljono Djoko.(2012). Buku Pintar Strategi Bisnis Koperasi Simpan Pinjam. Andi : Yogyakarta.

Nasution, Thamrin.(2006). Metode Penelitian Naturalistik. Jakarta : Sinar Grafika.

Nawawi Hadari.(2005). Penerapan Terapan. Yogyakarta : Gaah Mada University. Press.
Prawirosentono Suryadi.(2014). Kinerja. Bandung : Alfabeta.

Priatna, Suwatno.(2013). Perencanaan dan Pengembangan Sumber Daya Manusia. Bandung : Alfabeta.

Peraturan Menteri Koperasi dan UKM RI Nomor 9 Tahun 2018 tentang Penyelenggaraan dan Pembinaan Perkoperasian. Diunduh dari https://www.jdih.setneg.go.id diakses pada tanggal 1 November 2019.

Rangkuti Freddy.(2007). Strategi Promosi Yang Kreatif dan Analisis Kasus Integrated Marketing Communication. Jakarta : PT. Gramedia Pustaka Utama.

Rurchan Arif, (2012). Pengantar Penelitian dalam Pendidikan. Yogyakarta : Pustaka Pelajar.

Siagian Sondang.(2005). Fungsi-Fungsi Manaemen. Jakarta : Bumi Aksara.

Sitio Arifin.(2001). Koperasi Teori dan Praktik. Jakarta : Erlanggan.

Soejono, Sulistyowati.(2013). Sosiologi Suatu Pengantar. Jakarta : Rajawali Pers.

Sugiyono.(2013). Metode Penelitian Kuantitatif, Kualitatif, R\&D. Februari 2017. Bandung : Alfabeta.

Sugiyono (2014). Metode Penelitian Manajemen. Bandung : Afabeta.

Sugiyono.(2016). Metode Penelitian Kuantitatif, Kualitatif, R\&D. Cetakan Ke-24 Februari 2017. Bandung: Alfabeta.

Suharsimi Arikunto.(2013). Prosedur Penelitian. Suatu Pendekatan Praktik. Jakarta : Rineka Cipta.

Sumarsono Sonny.(2003). Ekonomi Manajemen Sumber Daya Manusia dan Ketenagakerjaan. Yogyakarta : Graha Ilmu.

Supardi.(2015). Penelitian Pendidikan Kelas. Jakarta : Bumi Aksara.

Undang-Undang Nomor 25 Tahun 1992 Tentang Pokok-Pokok Perkoperasian. Diunduh dari https://www.jdih.setneg.go.id diakses pada tanggal 1 November 2019.

Wirawan.(2014). Evaluasi Kinerja, Edisi Kedua, Jakarta : PT. Raja Grafindo Persada,

Yakin Hafsih Ipa.(2017). Metodologi Penelitian. Bandung : Karima. 